\title{
Analysis of the Energy Efficiency of Diesel Oil Consumption in the Brazilian Iron Ore Mining Company
}

\author{
Eunírio Zanetti Fernandes', Elisângela Martins Leal'2, Robson Lage Figueiredo3, \\ Gemírson de Paula dos Reis ${ }^{3}$ \\ ${ }^{1}$ VALE Technological Institute, Ouro Preto, Minas Gerais, Brazil \\ ${ }^{2}$ Department of Mechanical Engineering, School of Mining, Federal University of Ouro Preto, Minas Gerais, Brazil \\ ${ }^{3}$ Graduate Program in Instrumentation, Control and Automation of Mining Processes, School of Mining, Federal University of \\ Ouro Preto, Minas Gerais, Brazil \\ Email: eunirio.zanetti@itv.org, elisangelamleal@ufop.edu.br, robsonlage@yahoo.com.br, gemirson.reis@ufop.edu.br
}

How to cite this paper: Fernandes, E.Z., Leal, E.M., Figueiredo, R.L. and de Paula dos Reis, G. (2018) Analysis of the Energy Efficiency of Diesel Oil Consumption in the Brazilian Iron Ore Mining Company. Journal of Power and Energy Engineering, 6, 23-39.

https://doi.org/10.4236/jpee.2018.611003

Received: August 27, 2018

Accepted: November 20, 2018

Published: November 23, 2018

Copyright $(9) 2018$ by authors and Scientific Research Publishing Inc. This work is licensed under the Creative Commons Attribution International License (CC BY 4.0).

http://creativecommons.org/licenses/by/4.0/

\begin{abstract}
This paper aims to evaluate the diesel oil consumption between 2008 and 2015 in the production of iron ore in Brazil, creating correlations between energy intensity (production), economy and checking the impact of fuel prices on the commodity. During the analyzed period, the years 2008-2009 indicated economic crises, which interfered in the price and the commercialization of iron ore products. The physical intensity was $0.2 \%$ higher than the economic intensity. In the period from 2010 to 2014, economic activity remained more stable, with a decreasing trend, mainly due to the increase of iron ore prices. The physical intensity is much higher than the economic intensity influenced by the expansion of the Chinese economy. The year of 2014 indicated the end of the high iron ore price cycle and the beginning of supply and demand stabilization with consequent reduction in prices. In 2015, the market entered the stabilization phase, with a continuous reduction in unit production costs and transportation logistics. There was an abrupt change due to the strong increase of the economic intensity due to the fall of the international prices of iron ore. The diesel oil consumption plays a vital role in the scenario of cost reduction in iron ore production and a deeper analysis must be done in order to discover some options to change the energy matrix.
\end{abstract}

\section{Keywords}

Mining, Iron Ore, Diesel Oil, Consumption, Energy Analysis, Economic Analysis 


\section{Introduction}

\subsection{Iron Mining}

Mining is the search, extraction, beneficiation and processing of solid minerals from the Earth crust. Its extraction can be done mainly by open, underground and strips pits. Mining has been an essential part of human activity for thousands of years to supply raw materials responsible for both generating products that provide better safety and quality of life, and building the current industrial society. Some of the most important mining commodities in our society are iron, gold, silver, copper, tin, lead, diamond and coal. Minerals are defined as natural resource, stable at room temperature, represented by a chemical formula, biogenic that has an atomic or crystalline structure [1].

Iron is one of the most abundant elements of the Earth crust, corresponding to the percentage of $4.2 \%$. Among all metals, iron is the most produced and most present in our lives. Numerous minerals have iron as an essential component, but only oxides have high concentrations of this metal. The iron and steel industries around the world depend on iron ore as a primary source of iron. Because of this, the method used by companies to extract metallic iron from iron ore has to be economically feasible. A large majority of iron ore from mines is used as a feedstock to produce cast iron, which is then employed as the main component in steel. The main minerals that containing iron are: hematite $\left(\mathrm{Fe}_{2} \mathrm{O}_{3}\right)$, magnetite $\left(\mathrm{Fe}_{3} \mathrm{O}_{4}\right)$, goethite $(\mathrm{FeO} / \mathrm{OH})$ and siderite $\left(\mathrm{FeCO}_{3}\right)$. The ferrous formations composed of hematite and silica, called itabirites, constitute the largest iron deposits found so far [2].

The estimated World reserve of this mineral is about 170 billion tons of crude iron ore, and the percentage of iron ore represents 13.5\% of this total in Brazil according to [3] and [4]. Figure 1 shows the World reserves of iron ore. In this figure is shown the iron ore reserve indicating the metallic content, which makes up a reserve of 85 billion tons. In this case, Brazil represents $14 \%$ in iron content.

Mining has been outstanding in the last decades due to the development and industrial expansion of some countries around the World. This expansion is based on the massive introduction of large iron ore deposits that have emerged in recent years, frequently exceeding the needed requirement by the World market. In the face of this new expansion and great opportunity scenario, comes the idea of the efficiency of engines and equipment that will support these large investments, so the equipment has to be productive, effective and economical at the same time. Within open-pit mining, a cycle occurs in which all equipment plays a key role in mining, transporting and loading iron ore in the diesel oil consumption [6].

\subsection{Fuel Consumption in Iron Ore Mining}

Excavators and haul trucks are the main equipment for loading and hauling operations in open pit mines. These transport equipments consume $46 \%$ of mine 


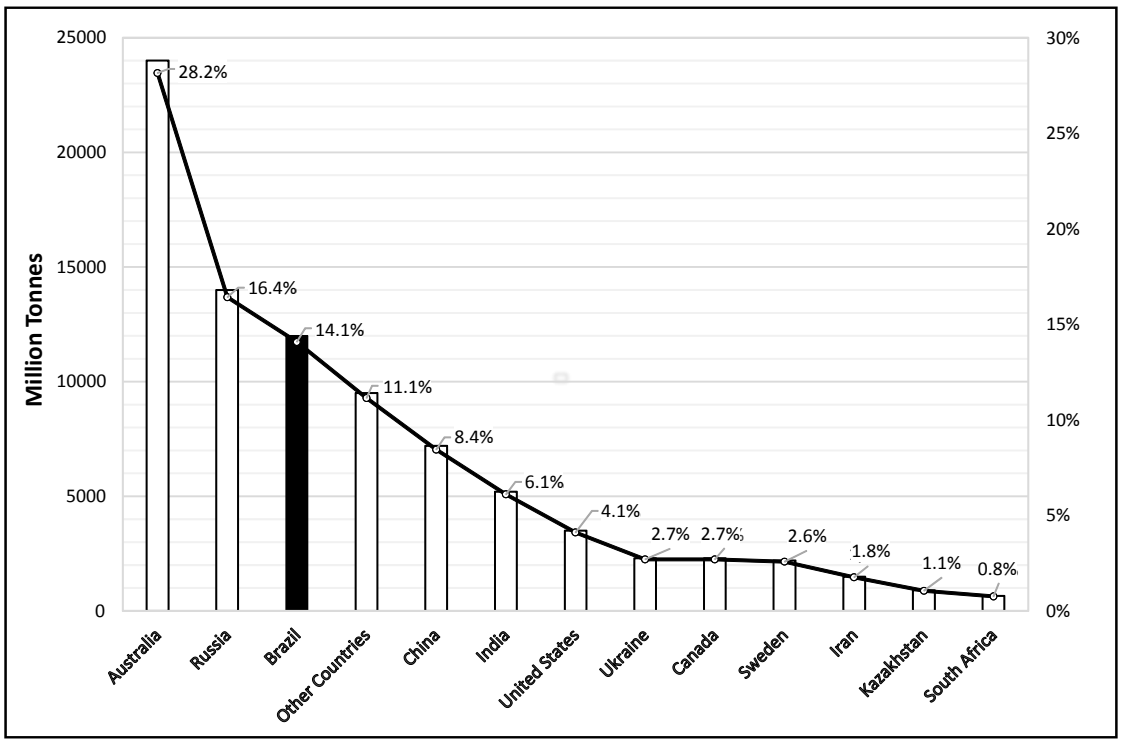

Figure 1. World iron ore reserves [5].

operation cost. Included in this percentage, the fuel is in the first position in consumption to the mine equipment [7] [8] [9].

A topography and deepening of the pit as well as the formation of higher waste piles has direct influence on fuel consumption [10]. The trucks must overcome the resistance generated by the friction of the tires with pavement and the inclination of the road. The performance of transport trucks depends on the design of mine transportation roads [11].

According to [12], in large iron mines, the ore overburden and transportation costs are directly related to diesel consumption. Due to the increasing demand for production, it becomes necessary to use off-road trucks with increasing capacities, leading to increased energy consumption.

Several uncertainties are influenced by the fluctuating demand of the market for raw materials and metals affecting commodity prices, and production costs such as mining, processing, administration and so on. These uncertainties include mineralized materials a mineral deposit can supply over time, technical, operational, and geotechnical parameters introduce risk sources in a business [13].

According to [14], realistic distribution of the actual costs of each product to a mining company is one of the main challenges. The assessment of each product's profitability may be impaired when incorrect information is provided and affect strategic decisions. [15] developed a set of cost functions for grinding mill equipment. The cost models used two approaches, which is a regression using one variable (UVR) and a regression employing some variables (MVR). The two approaches used the principal component analysis (PCA). The authors stated that the adequate cost estimation of mill plants plays a crucial role in the success of feasibility studies of mining projects, in which grinding is one of the most important operations in mineral processing plants. 
According to [16] and [17], the increase in indirect costs consequently the reduction of direct costs was both due to new management practices because the size of the mines and the increase in automation and outsourcing of non-end activities. Reference [8] conducted a study on the breakdown of 63 mines operating costs, dividing them into three main categories: mining, milling, and general and administrative costs. They have shown that the relative average costs of mining and milling are practically the same and the general and administrative costs account for a significant share of the overall cost. They also stated that understanding mine costs is an important tool for finding new unit operations and reducing costs.

According to [18], mining investments in Brazil reach proximally 15 US\$ billion per year, are expected to reach 53.6 US\$ billions of investments during the 2014-2018 cycle. Thus, there has been a race for mining companies' expansion around the World. With the large amount of this commodity and the sector competitiveness, companies make their operations leaner, with a smaller error margin, reducing unnecessary expenses. To meet this demand, mining machinery manufacturers have been working to build safer and more efficient machines in their operations in order to meet the miners' goals.

Overall, in 2015, price reductions continued for iron ore as China steel output declined, while projects to increase iron ore production capacity continued, mostly in Australia and Brazil. In these countries, the iron ore production, by gross weight, increased by 112 million of tonnes in 2013, by 116 million of tonnes in 2014, and by 29 million of tonnes in 2015 [19]. By contrast, the World steel demand declined by $3.0 \%$ in 2015 after an increase of $0.7 \%$ in 2014 , and is expected to increase by $1.3 \%$ in 2017 after an increase of $1.0 \%$ in 2016. In 2018, the global steel demand forecast is $0.9 \%$ [20].

The average monthly price of iron ore with $62 \%$ iron content decreased from 187.18 US\$/ton, price in February 2011 to 77.77 US\$/ton, price in September 2017 for which the prices were available. Because of the lower prices, about 200 million tons of iron ore capacity were inoperative between 2014 and 2015, mainly in Australia, Brazil, Canada, China, Sweden, the United States and West Africa. Additional capacity is expected to be placed on the market in the next 5 years, with 40 million tons in 2016 and 60 million tons in 2017 [3].

Extraction of iron ore is almost exclusively carried out in surface mines through open pit mining operations, which is characterized by high productivity and low safety risks compared to underground mining systems. However, this mining method has significant environmental impacts that need to be adequately assessed to make it a sustainable activity [21].

In this context, mining companies seek to reduce operating costs by controlling the diesel oil consumption. By applying techniques that reduce the use of supplies, the mining industry can become more economical and sustainable [22].

However, the mining sector does not have a methodology capable of selecting and measuring operational aspects that have more or less influence on fuel con- 
sumption. Filling this gap would represent a tangible method of managing and controlling truck operating costs. Effective control of fossil fuel consumption also improves the environmental performance of mining companies by reducing their emissions of greenhouse gases [10].

To understand the fuel consumption in mine transportation operations, one should not limit to the equipment mechanics. It is necessary to evaluate the influence of the human factor on the behavior of this variable. Operators' performance is supported by driving style. In addition, there are other associated conditions that influence the performance of the production process, such as climate and topographic conditions [12].

In recent decades, changes in demand, supply, and the exchange rate of the US dollar have induced fluctuations in the global iron ore prices [23]. The international iron ore market determines the prices through annual negotiations, which make it possible to plan the companies with the definition of the prices of these commodities before April of each year [24]. Through to the strategic nature of this resource, the price of iron ore is a significant economic parameter that deeply affects a country; the price volatility has a considerable impact on importing and exporting countries. For example, China has become the largest iron ore importer since 2003 , using more than $30 \%$ of the World's total production [25].

China external dependence reached $78.5 \%$ in 2014 [26]. China growing demand for iron ore inevitably accelerates the ore price, resulting in a negative influence in China purchasing power and in economic development [27]. Meanwhile, a large demand for iron ore also influences the exporting countries. As Australia and Brazil export more iron ore to China, these countries have reduced their exports to other countries, such as USA, Germany and France [27]. In addition, some exporting countries, such as Brazil, rely heavily on the commodity exports [28].

Iron ore is the main raw material in the crude steel production and is used to manufacture steel products [29]. Iron ore prices, like many other raw materials have fluctuated in the World market [23].

In order to predicting the price of iron ore in the long term, over five years, it was made in the cost study by three approaches: marginal cost approach and two approaches based on no incentive price calculation. The study was indicated, an increase between 20 and 30\% above the averages of iron ore prices predicted by analysts of the industries of the sector was predicted, an increase to values between 150 and 220 US\$/tonnage of iron ore. This forecast increase is mainly influenced by two factors: the depletion of existing iron ore deposits and the targeted return of investments for new iron ore mining projects [30].

Price fluctuations have a negative impact on both sides of the demand and supply of iron ore. For example, iron ore costs represent the largest proportion of output and directly affect the profitability of iron and steel companies [23]. High iron ore prices also raise producer and consumer indices through steel 
products, which could trigger inflation and other economic problems [31]. Meanwhile, when iron ore prices decreases, many mines can get into a difficult situation and may have to close their operations [23].

Crude oil is one of the most precious commodities in the World. Its price affects the economic market at all levels, from family budgets to corporate gains to the country GDP. Crude oil prices are also incredibly sensitive, changing rapidly in response to news cycles, policy changes and fluctuations in the World markets [32].

According to the Energy Information Administration [33], global demand and supply determine crude oil prices. Global economic conditions contribute to the demand for petroleum products produced from crude oil. As diesel is a major transportation fuel, demand for diesel fuel generally follows economic trends [34].

Changes in diesel prices reflect on crude oil prices. These changes are determined in the global market by the global demand and supply of crude oil [35]. The global economic crises of 2009 led to lower demand that contributed to lower diesel and crude oil prices [34]. With the global economic recovery underway, this combination of increasing demand and reduced supply helped to raise prices in recent years [36].

However, the recent price deceleration was a result of oil stocks growth, largely in the US, outpacing global demand growth [37]. According to the [33], in mid-2014 there was an oil prices declining trend, in a four-year phase of price stability. Figure 2 illustrates the variation of crude and diesel oil prices from 1994 to 2017.

The price of iron ore is determined not only by supply but also by other factors such as excess demand and high concentration. The US dollar has a significant influence on global commodities, including iron ore. Reference [39] highlights how the shock of depreciation of the US dollar has a marked effect on the price indices of iron ore, diesel and other commodities. References [40] and [26] prove that the US dollar has the biggest negative impact on the price of iron ore. Reference [41] assumes a causal relationship between US dollars and commodity prices. Figure 3 illustrates the price variations from 1994 to 2017 for diesel fuel and iron ore.

This work consists of the qualitative evaluation based on the bibliographic investigation procedure and the case study of a Brazilian mining company. According to [42], qualitative research has attributes such as general characteristics; data collect; study object; results interpretation and generalization.

The methodology consisted of the evaluation of diesel oil consumption in eight years (from 2008 to 2015) of iron ore production in Brazil, creating correlations between physical energy intensity, economic and checking the impact of diesel oil prices during this period. The unit of physical intensity is liters/ton handled in the year, diesel oil cost and gross revenue in US dollar. The diesel oil prices in US dollar per liter and unit production cost per ton handled, considering the total tonnage of ore and waste year by year in mining operations. 


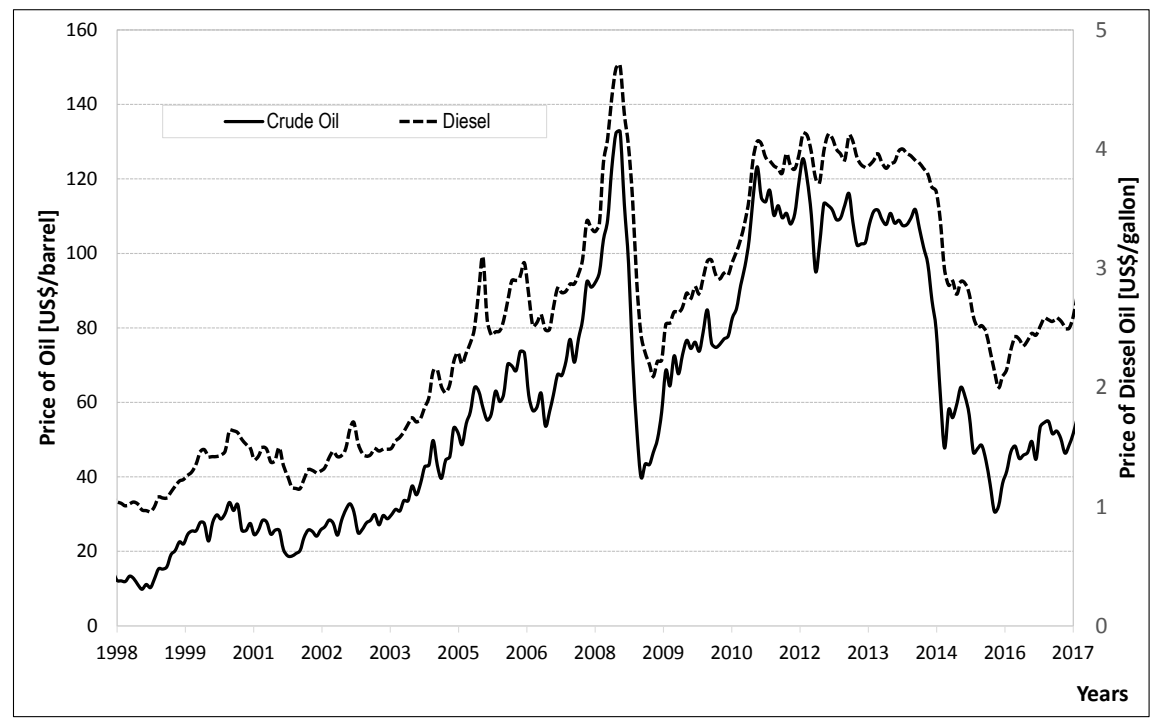

Figure 2. Comparison between the price of crude oil and diesel throughout the years of 1994 and 2017 [38].

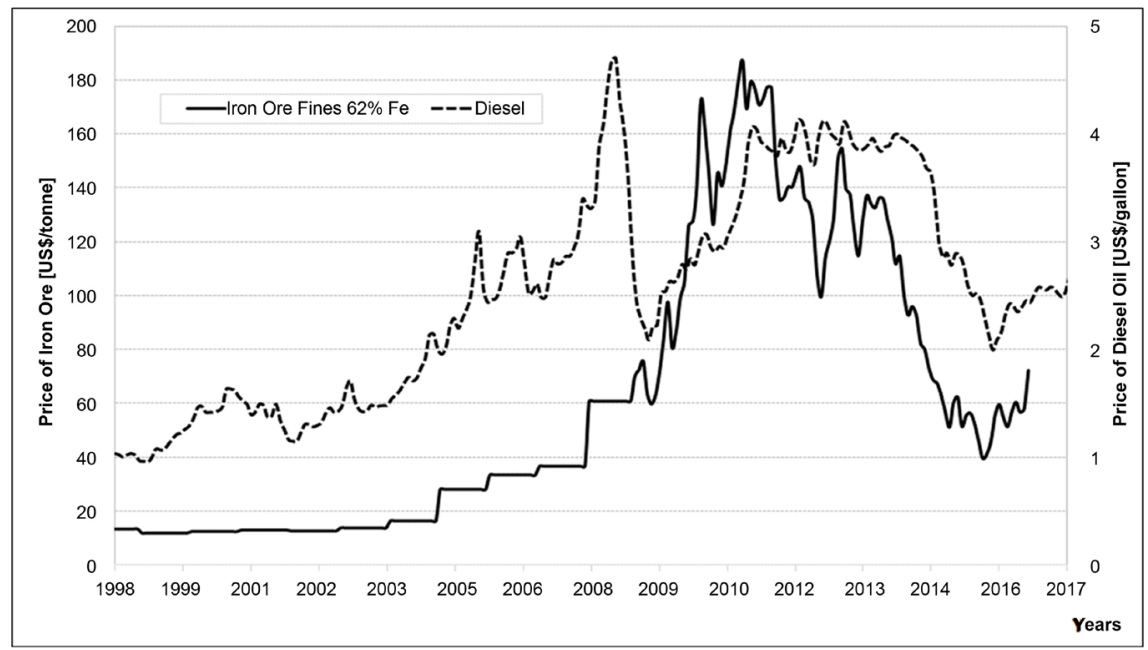

Figure 3. Comparison between Diesel oil and Iron Ore prices through the years of 1994 to 2017 [38].

\section{Results and Discussion}

Mine operations in the early stages consume less diesel oil because of the adequate transport profile, reducing the overall consumption. However, as the mine deepens, the consumption increases. Besides, loaded large trucks move on ascents, usually with gradients of 8 to 10 degrees, which can contribute to the increase of diesel oil consumption. On the other hand, the consumption increases by the continuous elevation of the stacks of sterile rock disposal. Depending on the size of the operations and the company, open pit mines are operationalized at various stages of maturity: deeper, intermediate and shallower, closer to the original surface. At each stage, fuel consumption varies widely and the introduction of new technologies to change the energy matrix and reduce average trans- 
port distances is essential in reducing costs.

The physical intensity of diesel oil consumption in iron ore mining operations has steadily increased over the last eight years due to two main causes: deepening of the pits and raising piles of waste material, which significantly increase the average transport distances. Figure 4 shows the physical intensity of diesel oil consumption during the years of 2008 and 2015.

According to Figure 4, between 2008 and 2009, physical intensity had a variation of $0.2 \%$ around the value of 0.22 liters/annual mining tonnage. The years from 2009 to 2013 presented an increase of $43.2 \%$ in the physical intensity from 0.22 to 0.32 liters/annual mining tonnage. In the last two years (2014-2015), there has been a stabilization of the diesel consumption (decrease of $0.2 \%$ around the value of 0.31 liters/annual mining tonnage), associated to the increase in the size of the transport trucks and the reduction of the number of trucks.

The economic intensity, which can be described as the impact of the acquisition cost of diesel oil to drive the thermal engines of a mining plant by the gross revenue from the sale of iron ore, is showed in Figure 5.

Figure 5 display the economic intensity of the diesel oil consumption which decreased 37.2\% in the period from 2008 to 2011 (excluding 2009) where the highest point (0.016 diesel fuel cost in US\$/gross revenue in US\$) is associated with the economic crisis, with a significant reduction in production. In the period from 2011 to 2014 (from 0.0099 diesel fuel cost in US\$/gross revenue in US\$ to 0.0143 diesel fuel cost in US\$/gross revenue in US\$), the economic intensity of diesel consumption rose by $44.2 \%$ year on year. In 2015 , the increase in economic intensity was higher than in previous years (up to 0.0255 diesel fuel cost in US\$/gross revenue in US\$) showing a strong upward trend of 78.6\%. The main reason is associated with a significant reduction in the international prices of iron ore products. By 2014 and 2015, the price reduction process had already begun indicating the reduction of economic intensity.

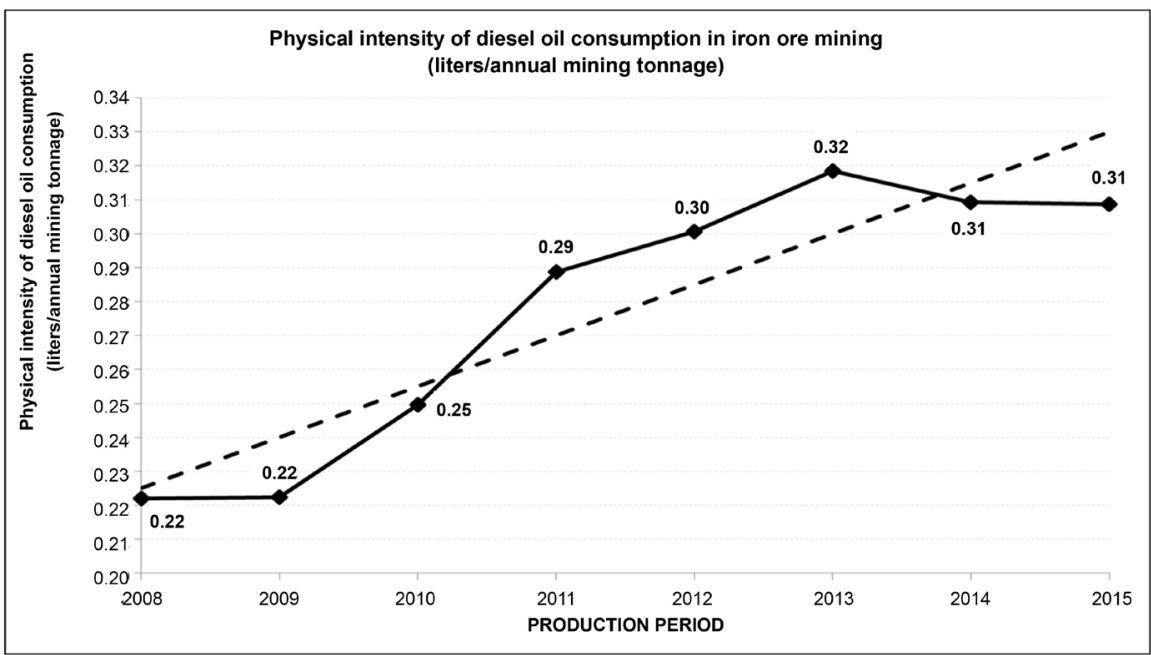

Figure 4. Physical intensity of diesel oil consumption from 2008 to 2015. 


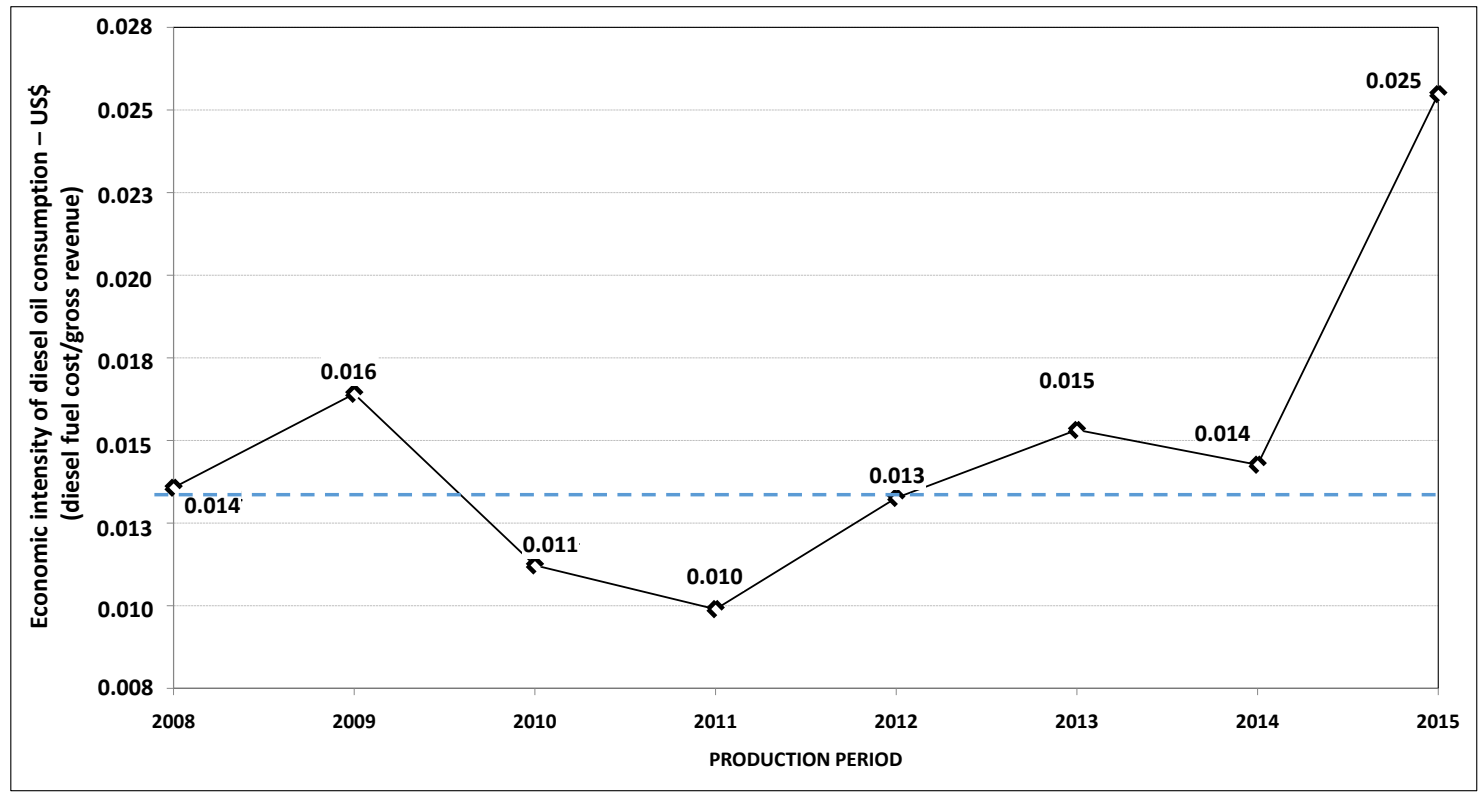

Figure 5. Economic intensity of diesel oil consumption from 2008 to 2015.

The economic intensity presents a behavior where some variables are important, which will depend mainly on the supply, demand and product quality profiles. The economic intensity takes into account the costs of production in its composition. Thus, at a time when commodity sales prices are at a lower level or at a time when world demand is high, continued productivity growth projects are highly desired to reduce economic intensity. In all scenarios of the iron ore market, continuous improvement programs are needed to reduce the vulnerability of the company.

Figure 6 shows the correlation between physical and economic intensities, with domains along the period analyzed. The correlation between physical intensity of diesel oil consumption (PIDOC) and economic intensities of diesel oil consumption (EIDOC) shows three main domains, as follow:

- PIDOC > EIDOC: the physical intensity of diesel oil consumption is a little higher than the economic intensity of diesel oil consumption in the years of 2008 and 2009. While there was a reduction in gross revenue of $26 \%$, the drop in consumption of diesel oil was $7.2 \%$, causing a drop in diesel cost of $4.5 \%$ to a practically constant physical intensity of diesel oil consumption (increase of $0.2 \%$ ).

- PIDOC >> EIDOC: the physical intensity of diesel oil consumption is much higher than the economic intensity of diesel oil consumption in the years between 2010 and 2014. The year of 2011 was the one where occurred the greatest variation between these two parameters. Physical intensity of diesel oil consumption reached the value of 0.29 liters/annual mining tonnage and the economic intensity of diesel oil consumption reached the value of 0.010 diesel fuel cost in US\$/gross revenue in US\$. This period represents the phase of higher iron ore prices in the expansion of the Chinese economy, mainly. 


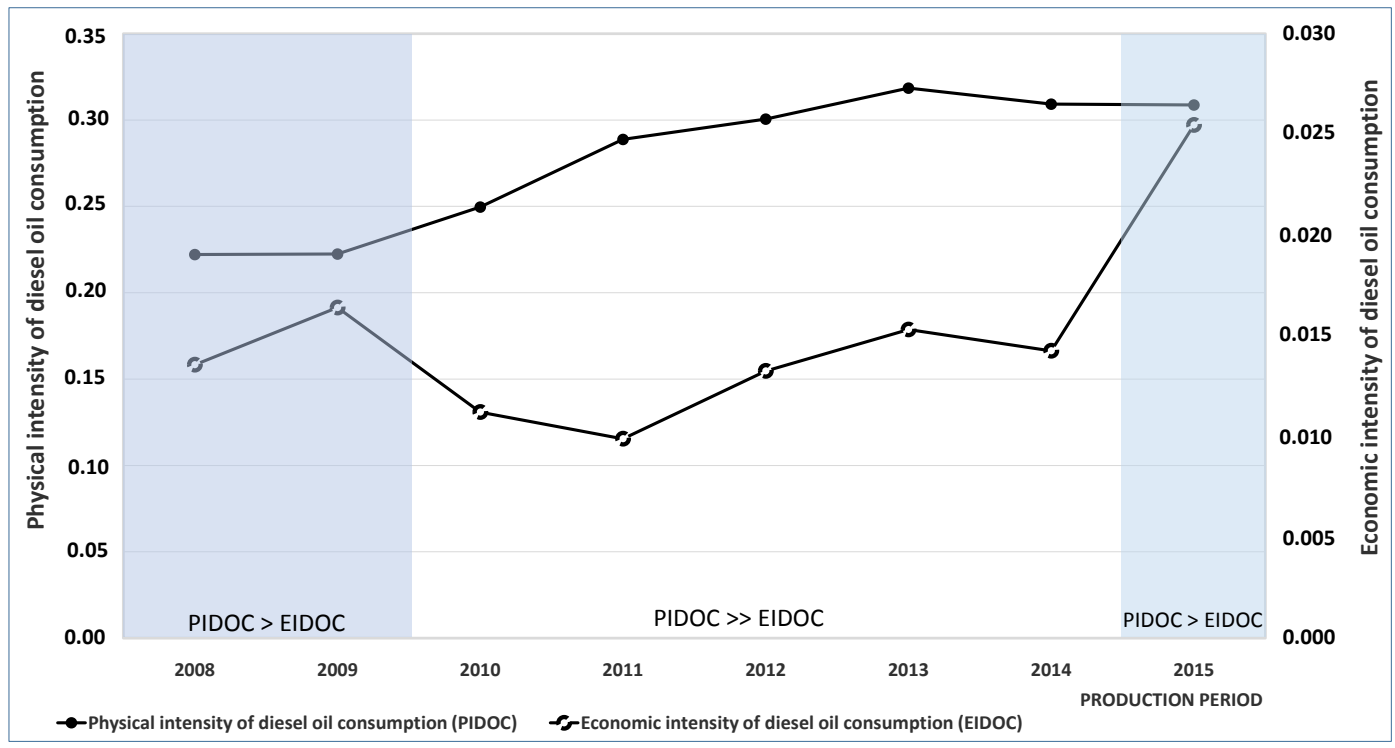

Figure 6. Correlation between physical and economic intensities of diesel oil consumption in the iron ore mining.

- $\quad$ PIDOC > EIDOC: there was an abrupt change in 2015 due to the strong increase of the economic intensity of diesel oil consumption due to the fall of the international prices of iron ore.

The three macro scenarios determined are closely associated with the economic cycles of supply and the demand for iron ore. The largest scenario is related to Chinese super-demand cycle, where the country's growth reached $10 \%$, with a significant increase in the raw material as a whole. The world's large mining companies increased their ore production in the period, but demand was higher and generated high iron ore prices. From China's reduced growth between 6 and 7 percent per annum, supply remained high, due to investments in the expansion of operations, and the less-demanded market was decisive in reducing product prices. The scenario has generated executive demands in companies to increase productivity and reduce costs to meet the new global reality.

Higher fuel prices from 2013-2014 onwards have had little influence on economic intensity. Figure 7 shows the average prices of diesel oil in Brazil.

As can be seen in Figure 7, between 2008 and 2012, the average price of diesel oil had an increase of $2.8 \%$, varying from 0.72 US $\$ /$ liter in 2008 to 0.74 US $\$ /$ liter in 2012. In 2015 the average price of diesel oil reached 1.12 US $\$$ /liter, an increase of more than 50\% considering the values practiced in 2012. The strongest change in 2015 was due to the reduction of iron ore commodities in the international market. In this year, compared to the previous years of 2013 and 2014, the economic intensity of diesel consumption increased more than $70 \%$. According to [43], in Brazil fuel prices were deregulated by law in January 2002, but in practice the national oil company, Petrobras, has frozen ex-refinery prices until 2012, with mounting losses. The Brazilian government adjusts a tax on diesel contributing to intervention in the economic domain, called CIDE (Contribuição e Intervenção no Domínio Econômico), to further stabilize retail prices. 


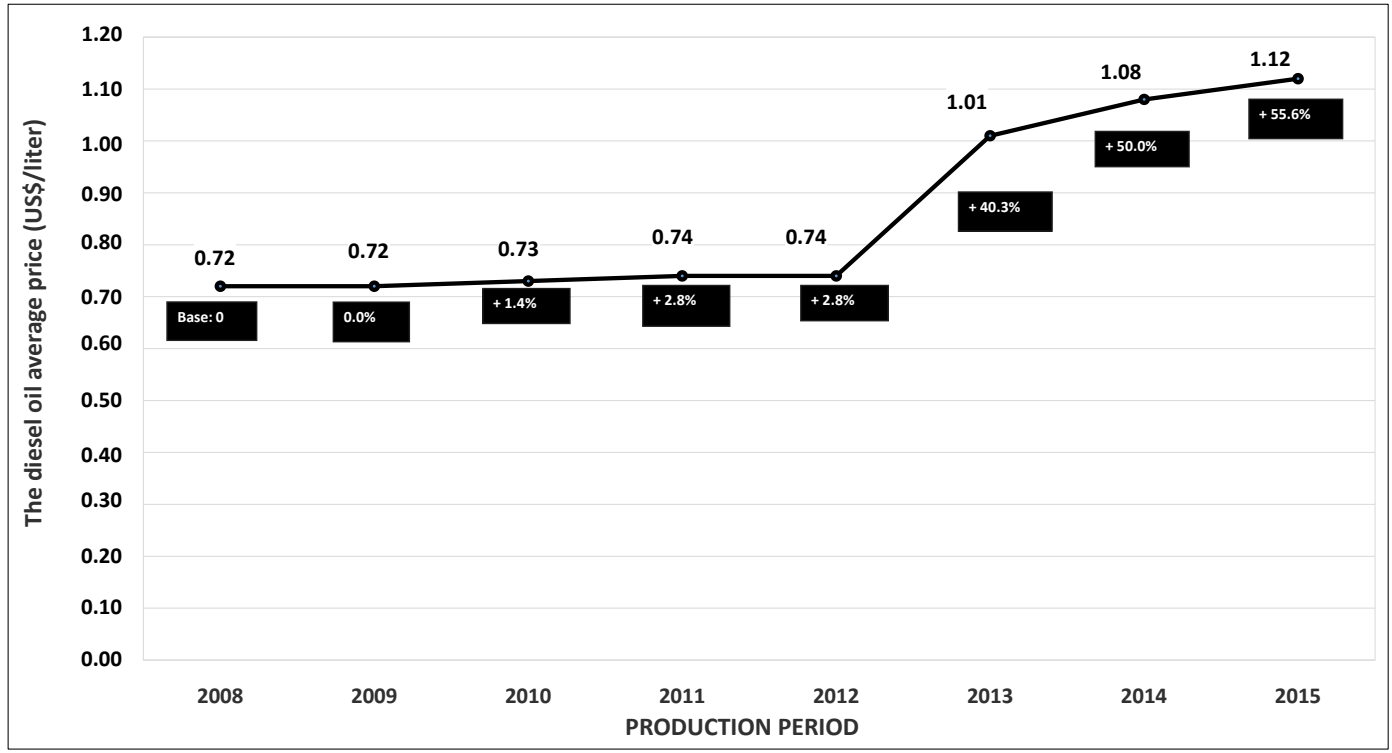

Figure 7. Average of diesel oil prices in Brazil.

In the medium and long term, the entry of foreign capital into Brazil for oil exploration may benefit diesel consumers. Therefore, the average prices of petroleum-based fuels can be reduced due to increased competitiveness. This is important for mining companies because they have a high consumption of inputs, representing $35 \%$ to $45 \%$ of operating costs. On the other hand, diesel consumers need to work with suppliers in order to obtain better quality fuels, establishing technical criteria for assessing the fuel input, which can positively affect the performance of the engines and, above all, the hourly consumption of the machinery.

Another important economic assessment is the correlation between the gross revenue generated (US\$) for the tonnage of iron ore production and the consumption of diesel oil (per liter). During the evaluated period, the variation was high, the average value was $79.46 \pm 15.93$ US\$/liter. Figure 8 shows five different phases in the eight years of iron ore production in Brazil.

In the period from 2008 to 2009 , the fall was due to the economic crisis, with reduction of sales quantities of iron ore and lower prices practiced, especially in 2009. The values varied from 79.75 US $\$ /$ liter to 67.63 US $\$ /$ liter, a variation of $-15.2 \%$. From 2009 to 2011, there was a strong resumption of higher prices (increase of more than 50\%), improving the gross financial return. The decrease in iron ore prices was significant from 2011 to 2012 of $-36.2 \%$, showing the change in the World scenario for those commodities, and the beginning of a new cycle of supply, demand and prices. From 2012 to 2014, there was a rise of about 15\% in prices (from 74.93 US\$/liter to 88.42 US\$/liter), but in 2015, there was a significant reduction of $-74.4 \%$ due to mainly the sales reduction and lower prices of iron ore, showing that the impact of the diesel oil consumption negatively affected the company's profitability.

Due to the stages of mines development in the operation and the introduction 


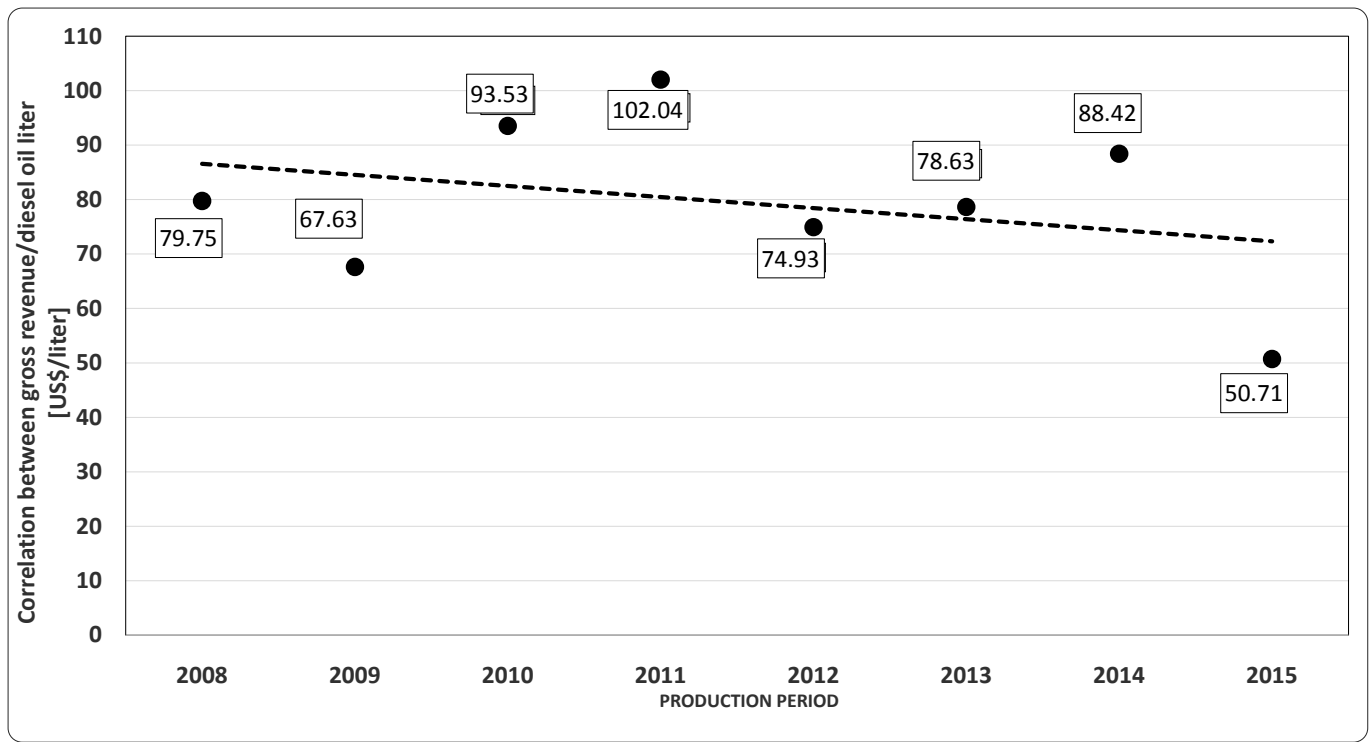

Figure 8. Correlation between gross revenue generated per diesel oil consumption.

of new pits in the production cycle, there is great difficulty in controlling the variable consumption of diesel in mining operations. Thus, all scenarios presented in the eight years of production (2008-2015) show great variability. Even considering these variables, Figure 8 indicates differences and denotes the need to structure the fuels consumption with the inclusion of changes in the energy matrix. The reality of increased lifetime consumption of a mine can be changed with tests of new technologies. In addition, consumption management is also required to assess the highest levels and allow for corrective action.

Figure 9 shows the annual diesel oil consumption cost per mining tonnage. The deepening of the mines and the elevation of the stacks of sterile rock disposal, increase the overall fuel consumption. Primary crushing stations are static and change position when large changes in mine geometry occur, or when open new mines. Conveyor belt designs can carry the material closer to the mine, reduce the average transport distance, and reduce the ore feed costs to the processing plants. Tillage sequencing can also devise the disposition of sterile rocks within the exhausted trenches, greatly reducing average distances and hence fuel consumption.

In Figure 9, one can notice that the trend of the diesel oil consumption cost per annual mining tonnage was increasing showing a variation around $40 \%$. Between 2008 and 2012, the impact of the cost of diesel oil consumption cost per annual mining tonnage rose by $10.5 \%$, from 0.24 US $\$$ /ton to $0.30 \mathrm{US} \$ /$ ton. From 2012 to 2013 , there was a significant growth of $22.1 \%$, from $0.30 \mathrm{US} \$ /$ ton to 0.38 US\$/ton. In the years of 2013 to 2015, the rise of this variable was lower (3.8\%), varying from 0.38 US $\$ /$ ton to 0.40 US $\$ /$ ton.

\section{Conclusions and Policy Implications}

The eight-year production data, from 2008 to 2015, shows a continuous increase 


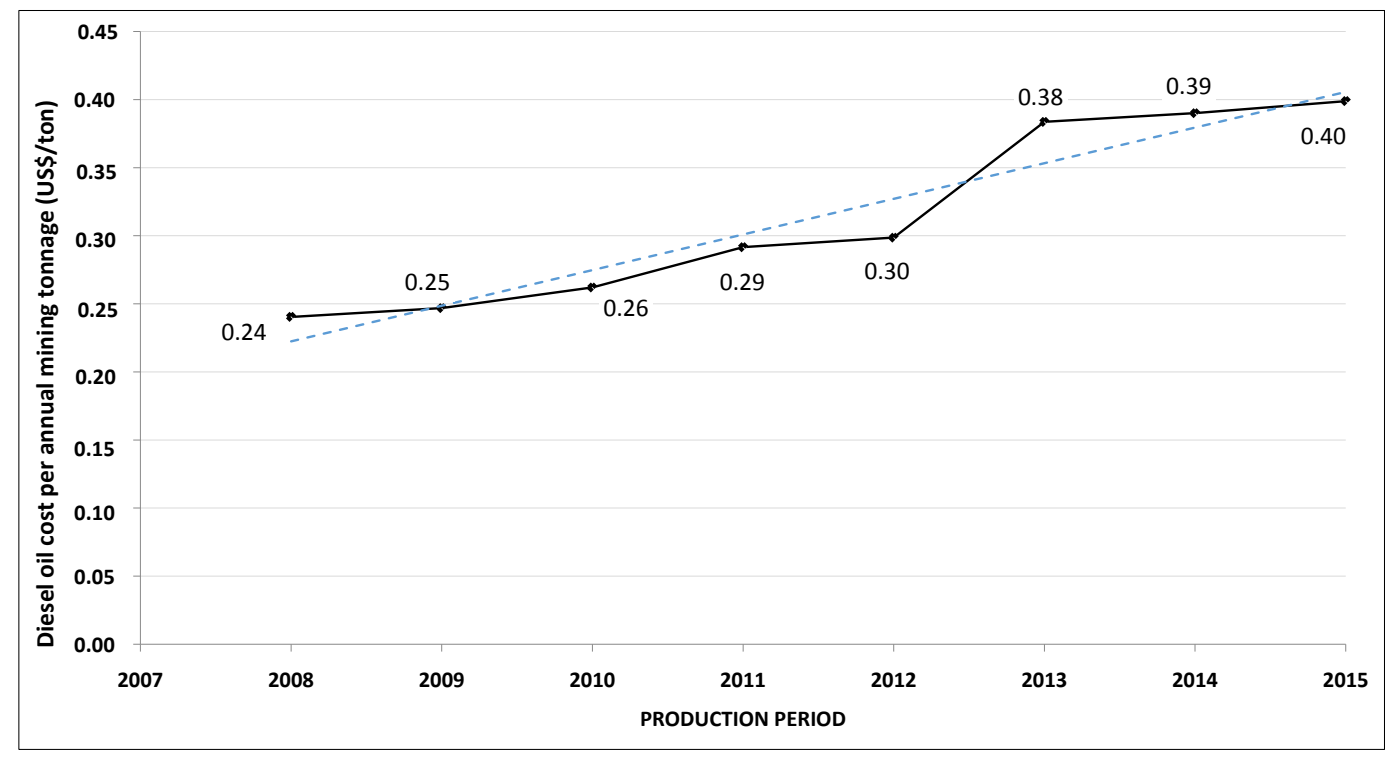

Figure 9. Diesel oil consumption cost per annual mining tonnage (US\$/ton).

in the diesel oil consumption in the production of iron ore in Brazil. The physical intensity showed the tendency of increase, based on the deepening of the mines pits and the disposal of waste rocks in higher parts. The rise in average transport distance has been made in the ramp's form, increasing diesel consumption even more.

In terms of economic intensity, the main variable that interfered in the period was the sale price of iron ore. The price of diesel in Brazil had a weak influence on the economic intensity. The results of the economic intensity are multivariate, depending on the behavior of the world market mainly supply, demand, and the quality of products sold. Production costs are important in the composition of economic intensity. Therefore, continuous productivity growth projects are very important to reduce the economic intensity, especially when sales prices are lower or when the world supply is higher. Continuous improvement project programs aim to reduce the company's vulnerabilities in all iron ore market scenarios.

The correlation between physical and economic intensities shows three main domains, which are: the years of 2008 and 2009 where the physical intensity is $0.2 \%$ higher than the economic intensity; between the years of 2010 and 2014 where the physical intensity is much higher than the economic intensity influenced by the expansion of the Chinese economy; and the year of 2015 where there was an abrupt change due to the strong increase of the economic intensity due to the fall of the international prices of iron ore.

The medium- and long-term expectations could benefit diesel consumers in Brazil, through the entry of foreign capital into oil exploration. Increasing competitiveness in the future may reduce the average prices of petroleum-based fuels and is an important target for mining companies that have high input consumption, accounting for $35 \%$ - $45 \%$ of operating costs. The large consumers of min- 
ing also need to invest in fuel quality control, establishing technical criteria for the evaluation of the input and the reflection in the engines and, mainly, the hourly consumption, being fundamental to act with the suppliers and demand assured the quality of the input.

The variability that showed in all the scenarios considered in the eight years of production indicates the difficulty of controlling the variable diesel consumption in the mining operations due to the stages of development of the mines in operation and the introduction of new pits in the production cycle. Tests with new technologies are necessary and may change the reality of increasing consumption over the life of a mine. Dynamic consumption management is also needed to assess the highest levels and allow for corrective action.

The raise in unit costs of diesel oil related to the movement of iron ore and waste in the operations is associated to two essential causes: increase of the depth of the mine caves and elevation of the waste piles. Both causes increase the average distance of transport, raising the consumption of diesel oil, mainly by the increase of the slopes, with loaded trucks.

In order to reduce the unit cost of production of iron mines through the physical and economic intensity of diesel oil, it will be necessary to change the current energy matrix. Detailed research through research and development projects in search of alternative solutions with natural gas and ethanol are fundamental in the partial replacement of diesel oil.

\section{Acknowledgements}

The authors acknowledge VALE, UFOP and CAPES for the support of this work.

\section{Conflicts of Interest}

The authors declare no conflicts of interest regarding the publication of this paper.

\section{References}

[1] Darling, P. (2011) Mining: Ancient, Modern and beyond. In: Darling, P., Ed., SME Mining Engineering Handbook, 3rd edition, Society for Mining, Metallurgy and Exploration, USA, 3-9.

[2] DNPM-Departamento Nacional de Produção Mineral (2011) Sumário Mineral 2011.

https://sistemas.dnpm.gov.br/publicacao/mostra_imagem.asp?IDBancoArquivoArq uivo $=6374$

[3] United States Geological Survey-USGS (2017) Mineral Commodity Iron Ore. https://minerals.usgs.gov/minerals/pubs/commodity/iron_ore/mcs-2017-feore.pdf

[4] Statista e the Statistics Portal (2015) World Reserves of Iron Ore by Country. http://www.statista.com/statistics/267381/world-reserves-of-iron-ore-by-country

[5] Golden Dragon Capital (2009) World Iron Ore Reserves. http://www.goldendragoncapital.com/world-iron-ore-reserves

[6] UNCTAD-United Nations Conference on Trade and Development (2009) The 
Iron Ore Market: 2008-2010. United Nations Publication, Genebra, 120 p.

[7] Bozorgebrahimi, E., Hall, R.A. and Blackwell, G.H. (2003) Sizing Equipment for Open Pit Mining-A Review of Critical Parameters. Mining Technology, 112, A171-A179. https://doi.org/10.1179/037178403225003591

[8] Curry, J.A., Ismay, M.J.L. and Jameson, G.J. (2014) Mine Operating Costs and the Potential Impacts of Energy and Grinding. Minerals Engineering, 56, 70-80. https://doi.org/10.1016/j.mineng.2013.10.020

[9] Da Cunha, R.E., Lima, H.M. and De Tomi, G. (2016) New Approach for Reduction of Diesel Consumption by Comparing Different Mining Haulage Configurations. Journal of Environmental Management, 172, 177-185. https://doi.org/10.1016/j.jenvman.2016.02.048

[10] Levesque, M., Millar, D. and Paraszczac, J. (2014) Energy and Mining-The Home Truths. Journal of Cleaner Production, 84, 233-255. https://doi.org/10.1016/j.jclepro.2013.12.088

[11] Thompson, R.J. and Visser, A.T. (2006) Selection and Maintenance of Mine Haul Road Wearing Course Materials. Mining Technology, 115, 140-153. https://doi.org/10.1179/174328606X155138

[12] Shafiee, S. and Topal, E. (2012) New Approach for Estimating Total Mining Costs in Surface Coal Mines. Mining Technology, 121, 109-116. https://doi.org/10.1179/1743286312Y.0000000011

[13] Ramazan, S. and Dimitrakopoulos, R. (2013) Production Scheduling with Uncertain Supply: A New Solution to the Open Pit Mining Problem. Optimization and Engineering, 14, 361-380. https://doi.org/10.1007/s11081-012-9186-2

[14] Cremonese, D.T., Tomi, G. and Neves, M.R. (2016) Cost Modelling of the Product Mix from Mining Operations Using the Activity-Based Costing Approach. REM-Revista Escola de Minas, 69, 97-103. https://doi.org/10.1590/0370-44672015690137

[15] Sayadi, A.R., Khalesi, M.R. and Borji, M.K. (2014) A Parametric Cost Model for Mineral Grinding Mills. Minerals Engineering, 55, 96-102. https://doi.org/10.1016/j.mineng.2013.09.013

[16] Sartorius, K.C. and Kamala, E.P. (2007) The Design and Implementation of Activity Based Costing (ABC): A South African Survey. Meditari Accountancy Research, 15, 1-21. https://doi.org/10.1108/10222529200700008

[17] Crowson, P. (2003) Mine Size and the Structure of Costs. Resources Policy, 29, 15-36. https://doi.org/10.1016/j.resourpol.2004.04.002

[18] Brazilian Mining Institute-IBRAM (2015) Investments in the Mineral Sector in Billions of US\$ (Statistics/Survey on Investments). Brazilian Mining Institute, Lago Sul.

[19] United States Geological Survey_USGS (2016) Mineral Commodity Summaries. https://minerals.usgs.gov/minerals/pubs/mcs/2016/mcs2016.pdf

[20] The World Steel Association (2017) Steel Recovery Strengthens, but Geopolitical Uncertainty Clouds Outlook.

https://news.metal.com/newscontent/100733361/steel-recovery-strengthens-but-geo politicaluncertainty-clouds-outlook/

[21] Ripley, E.A., Redmann, R.E. and Crowder, A.A. (1996) Environmental Effects of Mining. St. Lucie Press, Delray Beach, 356.

[22] Gomes, R.B., De Tomi, G. and Assis, P.S. (2015) Impact of Quality of Iron Ore Lumps on Sustainability of Mining Operations in the Quadrilátero Ferrífero Area. Minerals Engineering, 70, 201-206. https://doi.org/10.1016/j.mineng.2014.09.019 
[23] Astier, J. (2015) Evolution of Iron Ore Price. Mineral Economics, 28, 3-9. https://doi.org/10.1007/s13563-015-0068-x

[24] Li, J., Chen, J. and Wang, S.Y. (2011) Game Analysis in Negotiation of Iron Ore Price. International Series in Operations Research \& Management Science, 165, 161-185. https://doi.org/10.1007/978-1-4614-0511-5_7

[25] Ma, W.M., Zhu, X.X. and Wang, M.M. (2013) Forecasting Iron Ore Import and Consumption of China using Grey Model Optimized by Particle Swarm Optimization Algorithm. Resources Policy, 38, 613-620. https://doi.org/10.1016/j.resourpol.2013.09.007

[26] Chen, W.H., Lei, Y.L. and Jiang, Y. (2016) Influencing Factors Analysis of China's Iron Import Price; Based on Quantile Regression Model. Resources Policy, 48, 68-76. https://doi.org/10.1016/j.resourpol.2016.02.007

[27] Hellmer, S. and Ekstrand, J. (2013) The Iron Ore Would Market in the Early Twenty-First Century-The Impact of the Increasing Chinese Dominance. Mineral Economics, 25, 89-95. https://doi.org/10.1007/s13563-012-0021-1

[28] Haque, M.A., Topal, E. and Lilford, E. (2015) Iron Ore Prices and the Value of the Australian Dollar. Mining Technology, 124, 107-120. https://doi.org/10.1179/1743286315Y.0000000008

[29] Etienne, X.L. (2016) Irrational Exuberance in the Chinese Iron Ore Market. Applied Economics Letters, 24, 1161-1166. https://doi.org/10.1080/13504851.2016.1262507

[30] Pustov, A., Malanichev, A. and Khobotilov, I. (2013) Long-Term Iron Ore Price Modeling: Marginal Costs vs. Incentive Price. Resources Policy, 38, 558-567. https://doi.org/10.1016/j.resourpol.2013.09.003

[31] Zhu, W.-Q. and Xu, D.-Y. (2016) Analysis on the Influence Factors and Fluctuation of Iron Ore Price Based on Oligopoly Market. 3rd International Conference on Economics and Management (ICEM 2016), 5 p. http://dpi-proceedings.com/index.php/dtem/article/view/4038/3679

[32] Stehn, S.J. (2017) US Daily: Oil Supply versus Demand: A Market Perspective. Goldman Sachs Global Macro Research, New York City.

[33] Energy Information Administration-EIA (2017) Official Energy Statistics from the U.S. Government. Independent Statistics \& Analysis. U.S Energy information Administration, Petroleum \& Other Liquids Retrieved.

https://www.eia.gov/petroleum/data.php

[34] Hou, Z., Granoff, D., Granoff, I., Keane, J., Kennan, J., Norton, A., and Te Velde, D.W. (2014) The Development Implications of the Fracking Revolution. ODI Working Paper. Overseas Development Institute, London.

[35] Arezki, R. and Blanchard, O. (2014) Seven Questions about the Recent Oil Price Slump. https://blogs.imf.org/2014/12/22/seven-questions-about-the-recent-oil-price-slump

[36] Hamilton, J.D. (2014) The Changing Face of World Oil Markets. IAEE Energy Forum Newsletter, Cleveland. https://doi.org/10.3386/w20355

[37] Baumeister, C. and Kilian, L. (2015) Understanding the Decline in the Price of Oil since June 2014. CFS Working Paper No. 501, Frankfurt.

[38] Energy Information Administration-EIA (2017) Official Energy Statistics from the U.S. Government. Department of Energy. 2017 U.S. Petroleum Prices. http://www.eia.doe.gov

[39] Choi, K., Hammoudeh, S. and Kim, W.J. (2014) Effects of U.S. Macroeconomic 
Shocks on International Commodity Price. Korea and the World Economy, 14, 45-85.

[40] Ye, H.Y. and Li, J. (2012) Analysis of the Factors Affecting the Price of Imported Iron Ore in China. Economics, 10, 119-122.

[41] Zhang, H.J., Dufour, J.M. and Galbraith, J.W. (2016) Exchange Rates and Commodity Prices: Measuring Causality at Multiple Horizons. Journal of Empirical Finance, 36, 100-120. https://doi.org/10.1016/j.jempfin.2015.10.005

[42] Günther, H. (2006) Qualitative Research versus Quantitative Research: Is that Really the Question? Psicologia: Teoria e Pesquisa, 22, 201-210. (In Portuguese)

https://doi.org/10.1590/S0102-37722006000200010 Oliveira, P. and Almeida, E. (2015) Determinants of Fuel Price Control in Brazil and Price Policy Options. In: 5th Latin American Energy Economics Meeting, 2015.

https://www.iaee.org/en/publications/proceedingsabstractpdf.aspx?id=12675 